\title{
Application of Majapahit Architectural Elements in the Design of the Prapanca Secondary Market in Mojokerto, Jawa Timur
}

\author{
Anthony Andrey Wijaya ${ }^{1}$, Widiastuti ${ }^{2}$, I Ketut Mudra ${ }^{3}$ \\ Bachelor Degree of Architecture Study Program \\ Faculty of Engineering-Udayana University \\ Jimbaran \\ anthonyandreyw22@gmail.com \\ Architecture Study Program \\ Faculty of Engineering-Udayana University \\ Jimbaran \\ Architecture Study Program \\ Faculty of Engineering-Udayana University \\ Jimbaran
}

\begin{abstract}
The city of Mojokerto still has buildings that use elements of its local architecture. In the city which is also called the c ity of Majapahit, historical heritage influences contemporary architecture. Many public and commercial facility buildings use local elements, both in the appearance of buildings, zoning, and ornaments. The aim is to provide identity to the building. One of the efforts of the city government that has not yet been compiled is to rearrange the area or building area in terms of its revitalization. One of them is the Prapanca Market or also called the Flea Market. Commodities offered by this mar- ket are used goods that are not suitable to be returned to the market as a whole. The purpose of this design is to in- crease the vitality of this market through the use of local elements in the appearance of buildings. Revitalization is done by developing functions, zoning, and facilities. Local architectural elements are applied to the roof and body of the build- ing, as well as the entrance.
\end{abstract}

Index Terms — revitalization, local architecture, building facades, markets, mojokerto.

\section{INTRODUCTION}

Revitalization of the Prapanca Second-Hand Market in Mojokerto City is one of the efforts of the City Government in regulating and reorganizing areas that have decreased in vitality. Judging from the development of the market in Mojokerto is quite rapid, various commodities are traded there. The commodities offered are used goods or flea. Various kinds of goods are sold there such as motorcycle parts, scrap metal, electronic goods, household appliances and so on. The purpose of the Revitalization undertaken by the Mojokerto City Government is to reorganize the market area which is currently not feasible enough in conducting trading activities. Slum conditions and irregular arrangement of kiosks are one of the reasons for the Government's efforts to revitalize the market. In terms of the appearance of the building and the arrangement is inseparable from the touch of the Majapahit kingdom that dominated the development of architecture in Mojokerto. It is hoped that through this revitalization effort trading activities in the Prapanca market will return to normal. The use of local architecture with Majapahit style is expected to help strengthen the identity of the city of Mojokerto.

\section{Result AND ANAlisys}

\section{A. Element of Majapahit Architecture}

When he heard the word Mojokerto could not be separated from the history of the Majapahit kingdom in the village of Trowulan. Majapahit is one of the major empires that has ever developed in the archipelago and even has the 
largest area of influence in Southeast Asia. It is estimated that the center of the Majapahit Kingdom is located in Trowulan, Mojokerto Regency based on Raja Hayam Wuruk's travel notes as set out in the Negarakrtagama Book by Mpu Prapanca [1].

In a Javanese building you can usually find a lot of carved wood. This carved ornament contains symbolic meaning. This ornament has various kinds, for example mountains, tlacapan, roosters, snakes, banyu-drops, banaspati and so on. The form and meaning of the ornaments to be discussed here are limited to only a few commonly used ornaments).
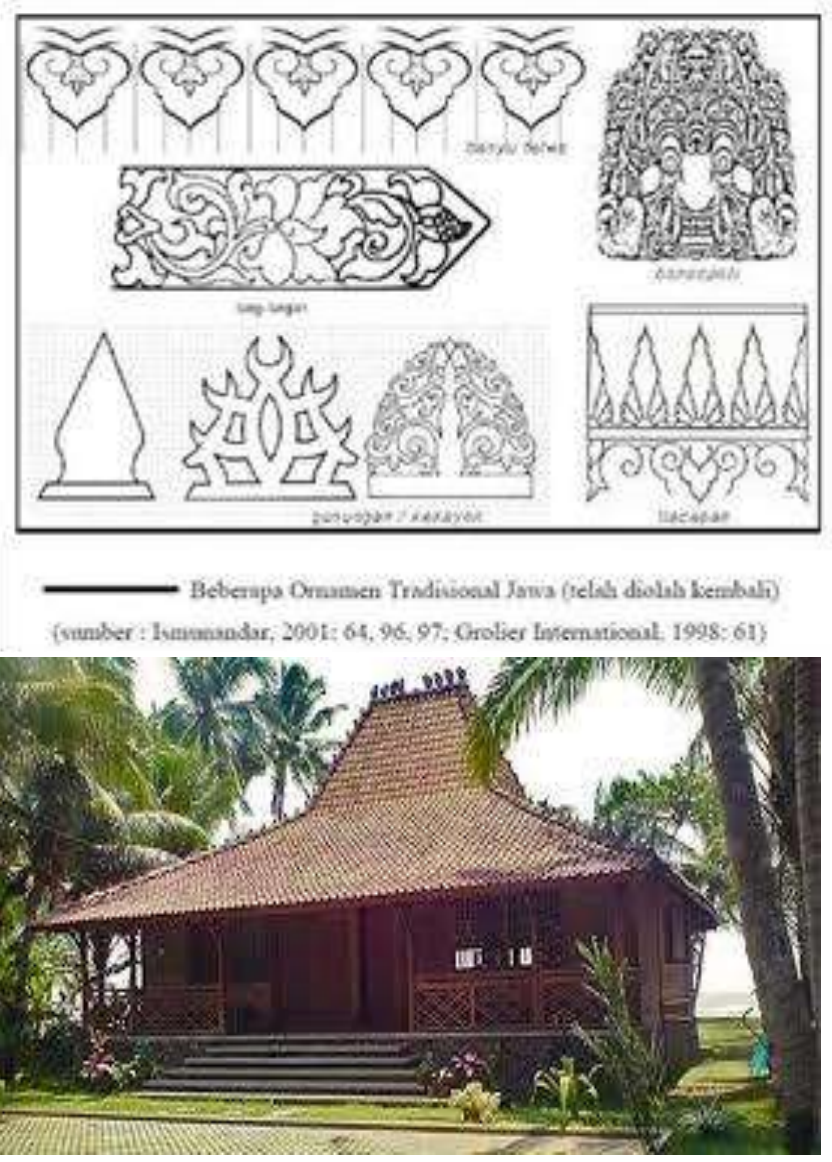

Fig. 1. Ornament and Joglo House (source: Wijaya)

\section{B. Implementation}

In the application of the elements of Architecture in Mojokerto, there are several aspects of the building that will be applied in the Application of Mojokerto Architecture in the pre-market Market Building Display. The following are some aspects of the appearance of buildings in the Application of Mojokerto Architectural Elements[2].

\section{Roofing}

The roof shape of the building uses the shape of the Joglo with varying slope as a characteristic of Local Architecture that can reflect the identity of the building. The slope of the roof of the joglo uses a slope of $20^{\circ}$ and $60^{\circ}$. And the use of more efficient metal roofing materials sees a considerable roof dimension. The use of joglo roof in Prapanca market building aims to make the building have an identity. Its function as a commercial area is a positive value for efforts to preserve the culture implemented in buildings in this modern era.

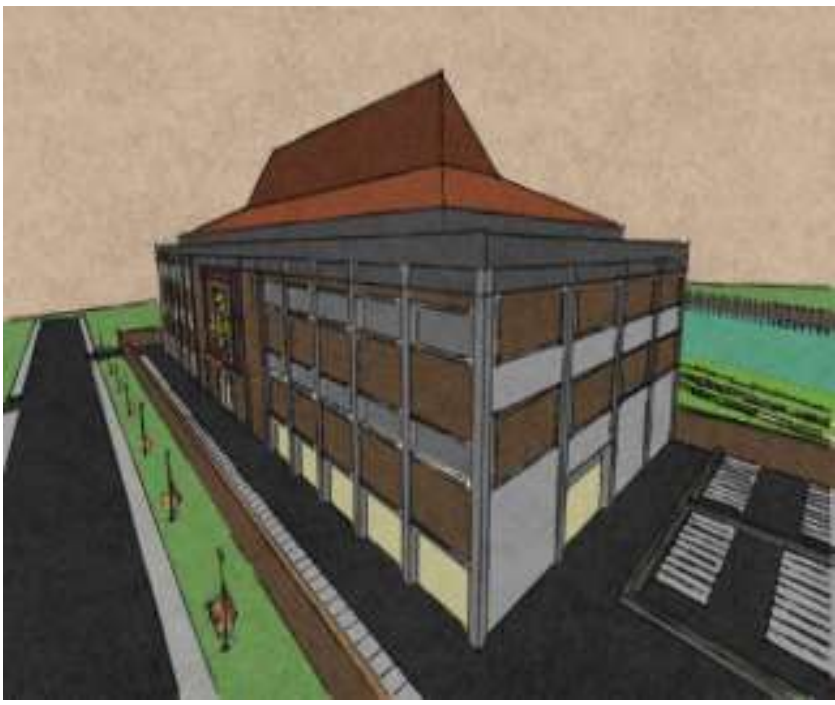

Fig. 2. Roofing Shape (source: Wijaya)

\section{Building}

In the body of buildings in some parts using brick and wood as ornaments characteristic of architectural identity in Mojokerto. (See Figure 3). The use of ornaments dominated by bricks on the front of the building gives a very strong value to the identity of the building. The unidirectional brick pattern gives a good aesthetic appearance. The use of brick ornaments is intended so that visitors when visiting have a harmonious impression when first entering or passing through the market area. The columns in the building do not use brick ornaments, only concrete and plaster without any special ornaments. The combination of local and modern ornaments has a positive value, so that the building is not rigid and there is harmony of ornaments that complement each other.

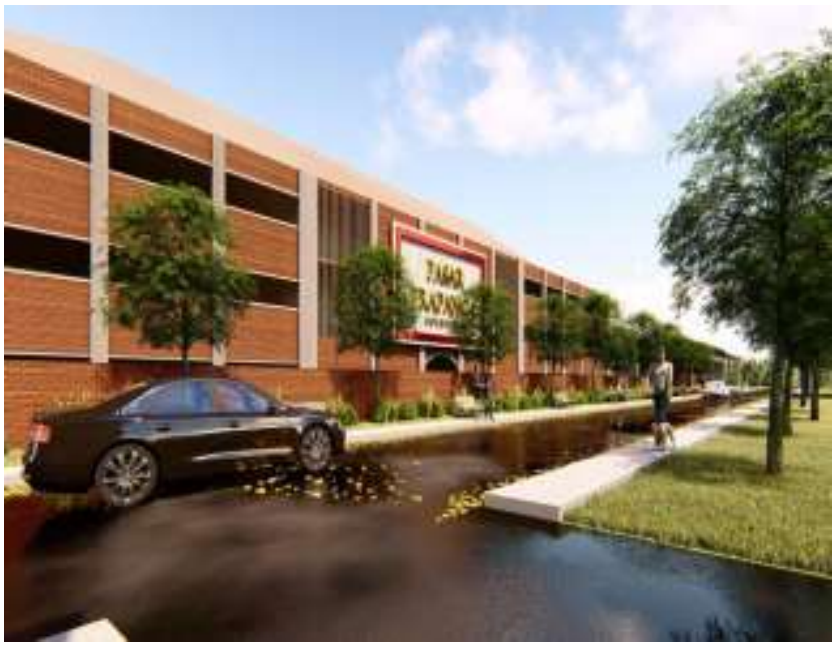

Fig. 3. Shape of the Building (source: Wijaya)

In the Prapanca market signboard using natural materials such as sandstone with a frame using brick ornaments. And on the side of the signboard using a wooden grill that makes the building more artistic. (See Figure 4). Prapanca market 
signboard is designed using stone carved by each letter. The shape itself is like a frame that has engraving on the edges. On the side of the signboard place a grill made of very sturdy wood. The aim is to make the appearance of the building more aesthetic and not flat or monotone using the overall brick ornament. The grill also aims to minimize incoming sunlight in the east.

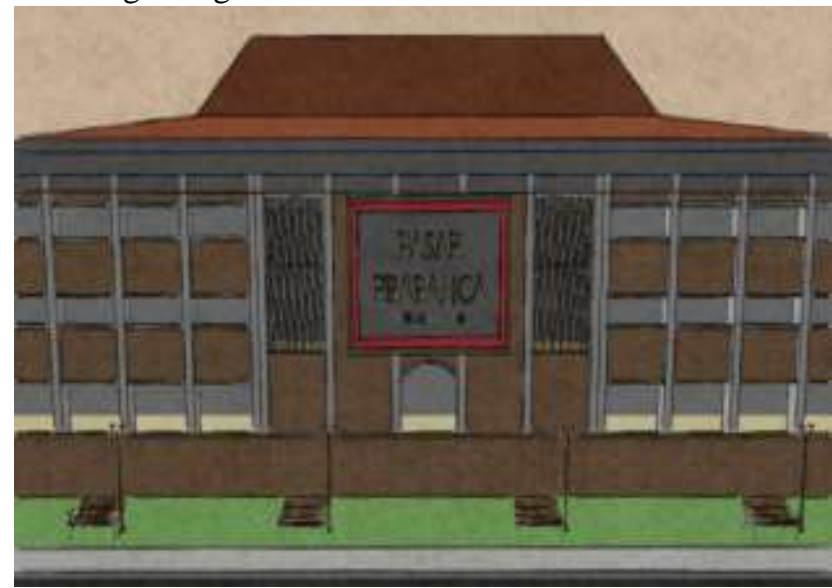

Fig. 4. Signboard (source: Wijaya)

The application on the rear view of the building combines brick ornaments and the use of steel in the ornaments used. In the application on the back of the building which is facing directly on the waterfront area, the brick ornaments used are not much like in the front. There are more openings in the area than the front view. Some parts are made like a frame in which the brick ornaments are given. And the other part is just a flat wall and also integrated by a grill made of steel that serves to minimize sunlight from the west. So that market visitors can enjoy a good view to the west facing directly with waterfront.

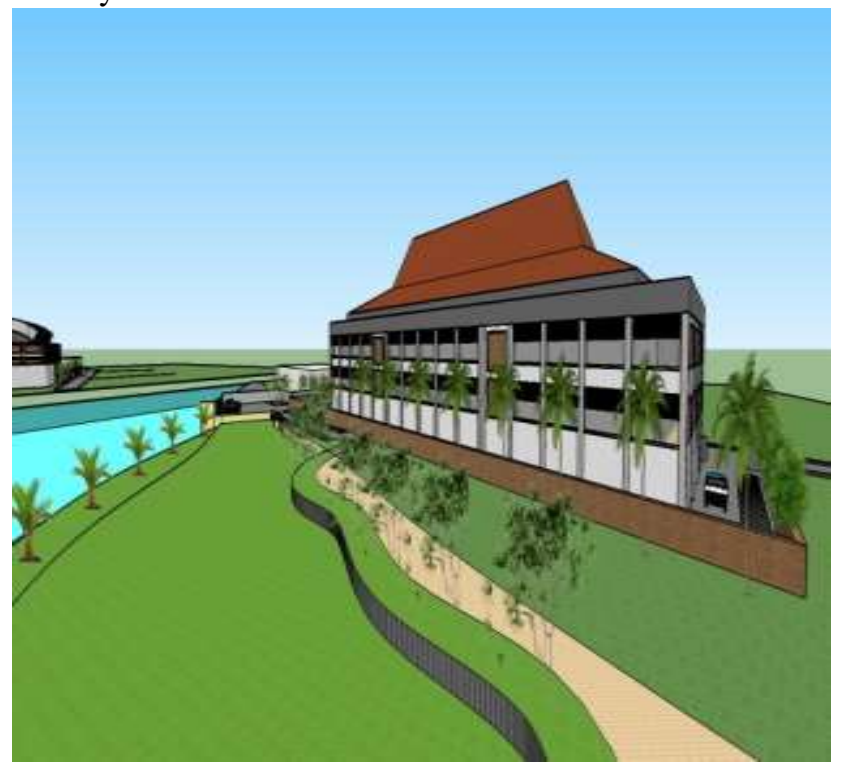

Fig. 5. Back Elevation (source: Wijaya)

\section{E. Entrance}

The shape of the entrance resembles an Alun-Alun Icon in the Center of Mojokerto City, by taking part in shape and using natural materials such as bricks to make it look very artistic. The shape part of the town square is aimed at giving visitors the impression of being very familiar with the area. The form is deliberately not taking from the form of a very typical temple in the city area of Mojokerto or Majapahit, because seeing from the function of the building itself in the form of a commercial area so as not to impress backwards the use of the icon of this square becomes one of the choices so that the building is better known from which area this building was built. With its large dimensions and also the material used using red bricks, it is a good collaboration between the concept of a modern form and its local material.

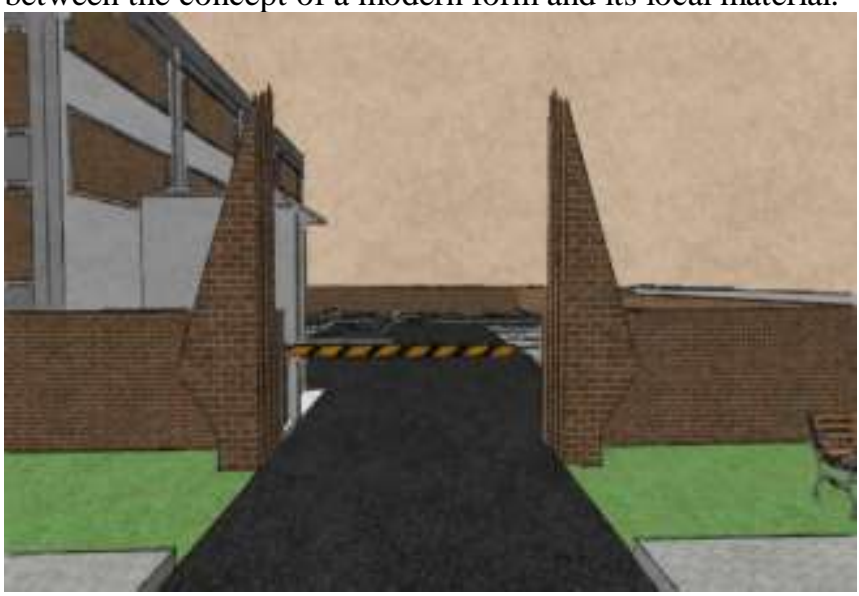

Fig. 6. Entrance (source: Wijaya)

\section{CONCLUSION}

Revitalization of the Prapanca Second-Hand Market in Mojokerto City is an effort by the city government to reorganize and revitalize a market that is no longer used. The market with a variety of used goods is still very much in demand by the local community and the public. With this planned revitalization, it is hoped that the buying and selling process and all the facilities in this market can be refunctioned properly. With maximum arrangement and concept it is hoped that this market has an identity that is not far from its function. By incorporating local elements that can make this market look very artistic. Between local and modern elements can be combined so as to indirectly participate in civilizing a traditional concept that will continue to be preserved. One concept of a market building that will be built in the modern era with a touch of some parts of local architecture such as the roof of Joglo and other display parts that can be surfaced. And using special ornaments in the area and some natural materials that can be used in building buildings in the modern era. By applying these local elements, it is expected that each commercial building in each area has its own characteristics so that it indirectly participates in preserving culture or a history that will be very meaningful in an increasingly modern era.

\section{REFERENCES}

[1] Sidomulyo, H, "Napak Tilas Perjalanan Mpu Prapanca", Jakarta: Wedatama Widya Sastra, 2007. 
Journal of A Sustainable Global South, p-ISSN: 2579-6062

[2] Darmasetiawan, Christian, Lestari Puspakesuma, "Teknik Pencahayaan dan Tata Letak Lampu Jilid 1 Pengetahuan Dasar", Jakarta: PT. Gramedia Widiasarana Indonesia, 1991. 